\title{
MODEL-MODEL KERUKUNAN UMAT BERAGAMA BERBASIS LOCAL WISDOM
}

(Potret Harmonisasi Kebhinnekaan di Nusa Tenggara Timur)

\author{
M ohammad Takdir \\ Institut IImu Keislaman Annuqayah (INSTIKA) \\ Email: mohammad.takdir@yahoo.com
}

\begin{abstract}
A bstraksi
Tulisan ini bertujuan untuk mengeksplorasi model-model kerukunan berbasis kearifan lokal yang dipraktikkan di NTT. Kerukunan berbasis kearifan lokal merupakan modal utama dalam menjaga persaudaraan dan kebersamaan diantara masyarakat. Meskipun provinsi NTT ditempati oleh sejumlah suku dengan budaya, agama, ras, dan golongan yang berbeda-beda, namun tidak lantas menjadi penghalang untuk merekatkan persatuan dalam kehidupan nyata.

Penelitian ini menggunakan pendekatan sosiologis untuk mengetahui bentuk harmoni sosial masyarakat NTT dalam memelihara kerukunan antar umat beragama. Penelitian ini menggunakan metode deskriptif untuk memperoleh pemahaman tentang nilai-nilai kearifan lokal yang menjadi kekuatan dalam memelihara kerukunan. Penelitian ini menggunakan studi kasus untuk memotret harmonisasi kebhinekaan di kalangan masyarakat NTT yang dikenal sangat majemuk.

Hasil penelitian ini menunjukkan bahwa nilai-nilai kearifan lokal di NTT merupakan modal sosial yang sangat besar bagi terciptanya kerukunan antar umat beragama. Adapun yang menjadi perekat utama terpeliharanya persatuan dan kerukunan antar masyarakat di NTT, diantaranya adalah khazanah budaya lokal, kekerabatan, semangat komunalitas, budaya rumah adat, dan kebersamaan dalam melakukan ritual keagamaan. Sementara itu, peran tokoh agama dan generasi muda juga menempati posisi strategis dalam mendorong terciptanya semangat persaudaraan secara integral.
\end{abstract}

Kata Kunci: Kerukunan, Umat Beragama, Local W isdom, NTT

\section{A. PENDAHULUAN}

Mengelola kemajemukan bukanlah perkara mudah untuk dilakukan. Pada satu sisi, umat beragama sebagai komponen bansga berusaha memelihara identitas dan memperjuangkan aspirasinya sendiri. Pada sisi lain, mereka juga dituntut untuk memberikan andil dan kontribusi signifikan dalam rangka memelihara kerukunan dan keutuhan bangsa. Dalam kondisi demikian, diperlukan kearifan dan kedewasaan di kalangan umat beragama untuk memelihara keseimbangan antara kepentingan kelompok dengan kepentingan nasional. Maka diperlukan format baru dalam 
menciptakan dan memelihara kerukunan umat beragama guna mewujudkan masyarakat Indonesia yang damai, aman, dan sejahtera.

Pembinaan kerukunan umat beragama sesungguhnya telah dilakukan melalui Depertemen Agama dengan berbagai gagasan yang pernah dibuat oleh para Menteri Agama dari waktu ke waktu. Setiap menteri menawarkan beberapa kebijakan yang berkenaan dengan masa depan kerukunan umat beragama sebagai prasyarat terciptanya kehidupan yang damai tanpa konflik. Kebijakan pemerintah untuk merukunkan umat beragama sebenarnya sudah jelas dan terarah, namun kenyataan di lapangan konflik-konflik bernuansa agama tetap terjadi dan menjadi keperihatian semua pihak. Lalu apa yang menjadi persoalan dan tantangan pembinaan kerukunan umat beragama di Indonesia?

Sejarah memang membuktikan bahwa bangsa Indonesia sudah dikenal sebagai masyarakat yang plural dengan segala macam keragaman yang ada. Di saat bersamaan, agama-agama yang berkembang di Indonesia telah menjadi bagian dari budaya dan aktifitas masyarakat. A kar-akar sejarah misalnya, memperlihatkan bahwa antara Hindu dan Islam terjalin hubungan yang harmonis, begitu dengan keduanya dengan Islam. Namun, antara Islam dan Kristen, hubungannya tidak sepenuhnya menggemberikan. Dalam pandangan ahli sejarah agama, ketiga agama besar sebelum tiba di Indonesia memang telah terlibat dalam hubungan pertentangan dan konflik, eksklusivisme, dan intoleran. ${ }^{1}$

Persoalan yang menyangkut tantangan pembinaan kerukunan umat beragama harus disadari cukup kompleks. Gejala dan ancaman disintegrasi yang menuntut kesadaran dan kontribusi berbagai pihak untuk menanggulanginya cukup dominan. Kesenjangan dan ketidakadilan ekonomi maupun kepentingan politik juga cukup mewarnai sehingga konflik meningkat cepat karena mereka yang bertikai melibatkan sentimen agama sebagai pemicunya. Persoalan tersebut kemudian merembet pada isuisu keagamaan yang sangat rentan diprovokasi untuk melakukan tindakan kekerasan. Semangat menonjolkan primordialisme juga terlihat marak dengan varian paguyuban kedaerahan belakangan ini. Primordialisme serupa ini bisa saja bermuara pada

${ }^{1}$ A bdul Fatah, “Kebijakan Pembinaan Kerukunan Hidup Umat Beragama dalam Masyarakat Plural is Indonesia," dalam Philipus Tuleand Maria Maltildis Banda, Pengembangan Kerukunan U mat Beragama D i N TT (Maumere: Ledarero, 2007), h. 63. 
eksklusivisme yang menegasikan sesuatu yang bukan suku, adat, ataupun agamanya. Kecurigaan ini akhirnya muncul dan berakibat pada melemahnya perekat-perekat sosial dan budaya lokal, fanatisme yang tidak pada tempatnya, dan klaim kebenaran yang berlebihan. ${ }^{2}$

Masalah penyiaran agama yang sering dilakukan tanpa disertai dengan kedewasaan dan sikap toleran terhadap pemeluk agama lain turut serta mewarnai berbagai konflik terjadi. Akibatnya, terjadi kasus-kasus pembujukan atau rayuan yang berlebihan atau bahkan pemaksaan yang sifatnya terselubung. Peristiwa ini dapat merusak hubungan antara umat beragama. Untuk menguranginya, pemerintah mengeluarkan SKB Menag dan Mendagri nomor 1 tahun 1979 tentang tata cara pelaknaan penyiaran agama dan bantuan luar negeri kepada lembaga-lembaga agama di indonesia. Peristiwa lain adalah terkait dengan perkawinan. Dalam masyarakat majemuk, perkawinan antar pemeluk agama yng berbeda sering menjadi pemicu terganggunya hubungan antar umat bergama. Hal ini terlihat ketika perkawinan dijadikan salah satu alat untuk mengajak pasangan agar pindah agama. Konversi agama seringkali dilakukan untuk mengesahkan perkawinan, namun setelah perkawinan berlansung beberapa lama, orang yang bersangkutan kembali ke agamanya dan mengajak pasangan untuk memeluk agama tersebut. ${ }^{3}$

Di berbagai tempat pola pengembangan kerukunan umat beragama telah dilakukan guna mengantisipasi meledaknya konflik yang lebih besar. Berbagai pembinaan dan penanaman nilai-nilai kedamaian didengungkan supaya setiap elemen masyarakat memiliki kesadaran akan pentingnya hidup rukun. Terlepas dari berbagai masalah dan tantangan kerukunan umat beragama, penulis mencoba menguraikan bagaimana potret kerukunan umat beragama yang terjadi dalam kehidupan masyarakat NTT. Daerah di Indonesia Timur ini, ternyata memiliki cara dan pendekatan sendiri dalam memelihara keharmonisan dan kerukunan antar umat yang plural. Dibandingkan dengan daerah lain, NTT termasuk wilayah Indonesia yang mengandalkan local wisdom sebagai fondasi dan kekuatan untuk membangun sebuah

2lbid., h. 64.

3 Muhammad Maftuh Basyuni, “Kebijakan dan Strategi Pembinaan Kerukunan Umat Beragama di Indonesia,"Ibid., h. 6. 
kehidupan tanpa kekerasan dan lebih mengutamakan pendekatan kultural sebagai nilai fundamental bagi seluruh suku yag ada di NTT.

\section{B. KAJIAN TEORI \\ a. Konsep Kerukunan}

Kerukunan seringkali menjadi perbincangan sehari-hari dalam kehidupan masyarakat, bahkan kerukunan telah dibicarakan secara berulang-ulang tanpa henti. Kerukunan adalah sebuah situasi yang selalu diidamkan oleh setiap orang yang mendamba kehidupan dengan penuh ketenangan dan kedamaian. Tidak heran bila Indonesia dikenal sebagai contoh dari kehidupan rukun yang selalu mementingkan kesejukan dalam menghadapi setiap permasalahan bangsa. Masyarakat Indonesia sadar bahwa tanpa kerukunan, bangsa ini tidak akan berdiri sebagai Negara Kesatuan Republik Indonesia, sehingga perbincangan seputar kerukunan selalu menempati posisi strategis dalam kehidupan berbangsa dan bernegara. Semua itu dilakukan untuk memelihara dan mengembangkan kerukunan diantara penganut agama yang berbeda, karena Indonesia adalah sebagai bangsa yang majemuk, yang tidak mempermasalahkan perbedaan keyakinan dari masing-masing individu. 4

Pertanyaanya, apa yang dimaksud kerukunan? Ada yang mengartikan kerukunan sebagai pilar atau tiang di mana "rumah" bangsa didirikan dan diciptakan. Kerukunan mengandung pengertian dinamis, yaitu pengakuan bahwa kendati masing-masing individu berbeda, tetapi tidak lantas harus bermusuhan dan bertikai satu sama lain. Memang juga ada sejenis kerukunan yang biasa disebut kerukunan semu (artifisial). Dalam kerukunan seperti itu, sekelompok orang yang tinggal dalam lingkungan yang sama, namun sama sekali tidak bersentuhan dan berinteraksi sebagai mahluk sosial. Situasi atau kondisi seperti itu tidak bisa disebut dengan kerukunan, karena tidak mencerminkan kebersamaan dalam keberagaman. Kerukunan seperti itu adalah jenis pelarian ketika orang tidak lagi mampu berhadapan dengan dunia yang riil.

Sementara, kerukunan autentik adalah ketika masing-masing individu berani melampaui bata-batas primordial, mengambil prakarsa secara cepat, dan tidak pernah 
mengedepankan prasangka dalam menjalin kehidupan sosial di masyarakat. Para tokoh agama memang memegang peranan kunci untuk mendorong kerukunan umat beragama, tapi tidak dapat bekerja sendirian atau sedekar bertindak sebagai pemadam kebakaran. Kemajemukan itu bukan dicari-cari atau direkayasa, tapi sudah begitu dari sono-nya, sesuatu yang given dari Tuhan. Maka setiap individuharus menyikapi kemajemukan itu dengan penuh kearifan, bukan malah merusak atau membunuh satu sama lain. Bagaimana mungkin situasi kerukunan bisa di bawa ke arah praksis (tindakan), kalau satu sama lain tidak bisa saling menghargai segala perbedaan yang ada. 5

Kerukunan berarti merasakan harmoni dan tiadanya permusuhan antar sesama yang menggambarkan hubungan antara kelompok yang berbeda karakter dengan tetap menjungjung tinggi sikap saling menghormati, keadilan, dan kehendak baik. Secara umum, kerukunan digambarkan dengan kehangatan, ketenangan, dan kesunyian tanpa kegaduhan dan perselisihan yang menganggu keharmonisan hidup. Konsep kerukunan seringkali dikaitkan dengan harmoni atau keselarasan dalam kehidupan manusia. Jika manusia merasakan harmonisasi dalam hidupnya, berarti ia bisa dikatakan hidup dengan rukun tanpa pertikaian, kekerasan, dan peperangan. Kehidupan yang rukun beberati menunjukkan suatu keharmonisan dalam sebuah masyarakat atau pun negara sehingga dapat berinteraksi dengan baik tanpa merasa ada gangguan dan ancaman yang datang dari siapa pun.

Kerukunan sesungguhnya tidak jauh beda dengan konsep damai dan harmoni yang selalu menjadi impian setiap orang untuk memperoleh ketenangan hidup dan jaminan keamanan dari segala ancaman kekerasan, kejahatan, dan peperangan yang seringkali menghambat terputusnya persaudaraan dan persahabatan antara sesama manusia. Ketika kerukunan menjadi dambaan setiap kelompok manusia tanpa membedakan latar belakang kehidupannya, maka cita-cita untuk terlepas dari ancaman kekerasan dan peperangan dapat menjadi kenyataan. Wahiduddin Khan menyatakan bahwa kerukunan yang menjadi cermin kedamaian selalu menjadi kebutuhan dasar bagi setiap manusia. ${ }^{6}$ Oleh karena itu, kerukunan merupakan hak

5A.A. Yewangoe, "Membangun Format Kerukunan Menurut Pandangan Kristen Protestan", dalamPhilipus Tule and Maria Maltildis Banda, Pengembangan Kerukunan U mat Beragama D i N TT, h. 27-29. 6Maulana Wahiduddin Khan, The Ideology of Peace (N ew Delhi: Goodword Books, 2010), h. 12. 
mutlak setiap individu sesuai dengan entitasnya sebagai makhluk yang mengemban tugas sebagai pembawa amanah Tuhan (khalifah fi al-ardl) untuk memakmurkan dunia ini.

Dengan suasana kerukunan, diharapkan akan tercipta dinamika yang sehat, harmonis dan humanis dalam setiap interaksi antar sesama, tanpa ada rasa takut dan tekanan-tekanan dari pihak lain. ${ }^{7}$ Tak seorang pun yang berpikiran sehat akan memilih konflik sekiranya kerukunan masih dapat diusahakan. Akan tetapi juga tak sesorang pun dari masing-masing orang yang mendambakan kemajuan, akan memilih kerukunan dan ketenteraman yang pasif dan statis. Dalam pandangan Eka Dharmaputra, secara objektif syarat untuk membina kerukunan hidup bersama telah tersedia dan sasaran yang akan dituju sudah jelas. Masalahnya hanyalah kesadaran, kemauan, usaha dan kerja keras dari masing-masing individu untuk mengendalikan egosentrisme dan fanatisme yang berlebihan. ${ }^{8}$

Dalam konteks hubungan antar agama, kerukunan menjadi sesuatu yang sangat penting bagi kehidupan masyarakat. Pentingnya kerukunan tidak lepas dari potensi konflik yang bisa saja datang secara tiba-tiba dan hal itu harus dibangun sejak dini. Kerukunan berarti suasana kehidupan umat beragama yag bersatu hati hidup berdampingan atas dasar saling menghormati, menghargai, dan bebas dari intervensi sehingga menciptakan damai lahir dan batin serta suasana hidup yang saling membantu. Kerukunan umat akan menciptakan ketenteraman umum, memperkokoh persatuan dan kesatuan bangsa hingga menciptakan kesejukan hati bagi kehidupan masyarakat. ${ }^{9}$ Kerukunan hidup adalah suatu kondisi sosial dimana semua golongan agama hidup bersama-sama tanpa mengurangi hak dasar masing-masing untukmelaksanakan kewajiban agama. Dalam kehidupan mayarakat, kita ingin hidup rukun dengan siapa pun tanpa memandang latar belakang kehidupan. ${ }^{10}$

\section{b. Kearifan Lokal sebagai N ilai Fundamental}

7Eka Hendry Ar, Sosiologi Konflik: Telaah Teoritis Seputar Konflik D an Perdamaian (Pontianak: STAIN Pontianak Press, 2009), h. 151.

8Eka Darmaputera, Toleransi: Kerukunan Pembangunan (Jakarta: Badan Penerbit Kristen, 1971), h. 30.

${ }^{9}$ Chatib Thoha, M embiarkan Berbeda: Kerukunan H idup Beragama D alam Perspektif Keindonesiaan (Yogyakarta: Pustaka Pelajar, 2004), h. 59.

10AP. Budiyono, M embina Kerukunan H idup A ntar U mat Beriman (Yogyakarta: Kanisius, 1983), h. 227. 
Pada bagian sebelumnya, sudah dijelaskan tentang makna kerukunan sebagai cerminan dari kehidupan damai dan tenang tanpa adanya suatu pertikaian yang melibatkan dua belah pihak yang saling menyerang satu sama lain. Pemaknaan yang tak kalah pentingnya adalah mengenai kearifan lokal (local wisdom) yang menjadi kekuatan fundamental bagi setiap daerah dalam mempertahankan tradisi kultural yang sudah berkembang secara turun-temurun. Dengan memahami pengertian kearifan lokal, kita bisa mencerna lebih mendalam mengenai kekhasan kebudayaan suatu daerah yang mampu merawat kehidupan dengan penuh kebijaksanaan sesuai dengan tradisi dan kepercayaan masyarakat setempat.

Kearifan lokal terdiri dari dua kata, yakni kearifan dan lokal. Kearifan berasal dari kata "arif", yang berarti tau atau mengetahui. Kearifan bisa berarti kebijaksanaa, kecerdikan, atau kepandaian yang merepresentasikan pengetahuan seseorang terhadap hakikat kehidupan. Sedangkan lokal berarti daerah atau suatu tempat yang memiliki karakteristik masing-masing sebagai sebuah kekayaan atau mozaik yang menjadi modal sosial bagi masyarakat. Jadi, kearifan lokal adalah berupa gagasan, nilai, dan tindakan yang menjadi kebudayaan suatu daerah dengan keunikan dan kekhasannya yang luar biasa. Dengan kata lain, setiap tradisi atau kepercayaan yang ada di suatu daerah, termasuk bagian dari kearifan lokal yang menjadi keunikan dan daya tarik bagi masyarakat.

Kearifan lokal dalam disiplin ilmu antropologi, juga dikenal dengan istilah“'local genius, yang pertama kali diperkenalkan oleh Quaritch Wales. Dalam pandangan A yatrohaedi, kearifan lokal adalah "the sum of the cultural characteristic which the fast majority of a people have in common as a result of their experiences in early life".11 Dalam kearifan lokal mencerminkan kemampuan kebudayaan setempat dalam menghadapi pengaruh kebudayaan luar yang semakin memberikan tekanan terhadap segala tradisi yang berkembang di masyarakat. Kearifan lokal juga bisa dipahami sebagai sebuah gagasan, perilaku, atau tindakan yang bersifat murni dari tradisi dan kepercayaan masyarakat berdasarkan pengalaman hidup di suatu daerah yang masih mempertahankan kebudayaan sebagai hasil karya, cipta, dan karsa bagi mereka. 
Dalam kehidupan masyarakat pedesaan atau pedalaman, kearifan lokal menjadi modal sosial yang sangat tinggi nilainya dibandingkan dengan arus globalisasi yang menawarkan kemewahan dan kebebasan bagi masyarakat untuk bertindak sesuai selera atau kebutuhan kebudayaan luar. Kearifan lokal di tengah-tengah kehidupan masyarakat diyakini bisa menjaga warisan budaya leluhur sebagai bentuk penghormatan yang monumental bagi terciptanya keseimbangan hidup di alam semesta ini.

Kearifan lokal memang identik kebijaksanaan yang terdapat dalam kehidupan suku-suku di berbagai daerah. Kearifan lokal di dalamnya tidak sekadar gagasannya dalam bentuk ilmu pengetahuan, tapi juga pada pola tindakan yang menghasilkan budaya tertentu sebagai sebuah warisan yang monumental. Tidak heran bila wacana tentang kearifan lokal dalam suku-suku tertentu, selalu terkait dengan tuntutan perubahan atau modernisasi. Maka, sebuah masyarakat yang masih memegang teguh kearifan lokal mereka, sebisa mungkin tidak terpengaruh kebudayaan luar yang tidak sesuai dengan nilai-nilai luhur yang mencerminkan filosofi hidup di dunia. Hal ini sesuai dengan apa yang dikatakan Fred Wibowo, bahwa nilai-nilai kearifan dalam bentuk apa pun harus dipertahankan, karena merupakan warisan kebudayaan yang tak ternilai harganya.12

\section{Model Kerukunan Berbasis Sosio-Kultural di NTT: Aktualisasi Nilai-Nilai Kearifan Lokal dalam M erawat Kebhinnekaan}

Implementasi kerukunan umat beragama di Indonesia tampaknya masih cenderung menggunakan kebijakan yang berisi peraturan-peraturan yang sifatnya mengekang dan terlalu dipaksakan untuk daerah-daerah berpotensi menimbulkan konflik. Strategi yang demikian tampaknya harus dikaji ulangdalam rangka menampung aspirasi dan keinginan masyarakat yang berkonflik sehingga tumbuh kesadaran sendiri untuk menata kembali kemajemukan yang sudah menjadi bagian penting dari kehidupan masyarakat.

Kemajemukan merupakan potensi luar biasa yang harus dipelihara dan dikembangkan secara holistik sebagai fondasi fundamental dalam merangkul keragaman menjadi kebersamaan yang humanis. Kemajemukan ini secara normatif

12Fred Wibowo, Kebudayaan M enggugat: M enuntut Perubahan A tas Sikap, Perilaku, Serta Sistem Yang Tidak Berkebudayaan (Yogyakarta: Pinus Book Publisher, 2007), h. 220. 
tidak bisa diinterpretasi akan mengancam stabilitas sosial-politik Indonesia, bahkan mungkin dapat menjadi langkah primordial dalam menyatukan keragaman dengan penuh ketulusan. ${ }^{13}$ Kenyataan ini harus dipahami sebagai anugerah dari Tuhan untuk membangun kerukunan di tengah keragaman demi terciptanya harmonisasi kehidupan yang lebih egaliteral dan berkeadilan. Potensi kemajemukan yang membawa kerukunan dan kedamaian tercermin dari kehidupan masyarakat NTT yang bisa dijadikan contoh bagaimana keniscayaan pluralitas dipelihara dengan sangat menawan dan mengagumkan melalui potensi local wisdom yang sampai ke akar rumput (grass root).

Meskipun NTT terbilang daerah yang sangat majemuk, namun potensi konfliknya hanya bersifat aksidental. Lalu bagaimana sebuah wilayah Indonesia yang sangat majemuk, mampu membingkai sebuah model atau format kerukunan dan kedamaian secara totalitas? Potensi dan khazanah apa yang sebenarnya dibangun masyarakat NTT dalam memelihara kerukunan di tengah keragaman ini? A pa yang menjadi faktor pemersatu masyarakat NTT dalam membina dan memelihara kerukunan di tengah keragaman? Tentu model atau format kerukunan yang dipraktikkan di NTT bisa menjadi contoh yang baik bagi daerah lain untuk mengoptimalkan potensi dan khazanah lokal menjadi sebuah instrumen penting dalam mengelola sebuah kedamaian yang menjadi cita-cita bersama di negeri ini.

Masyarakat NTT memiliki nilai-nilai dan norma-norma budaya yang sangat menjunjung tinggi kearifan lokal(local wisdom), menjamin serta mencirikhaskan kerukunan dan toleransi, perdamaian dan persatuan, persaudaraan dan kekeluargaan, solidaritas dan kerjasama, bukan hanya antar umat beragama, tetapi antar setiap individu dan kelompok dari latarbelakang manapun. Kearifan-kearifan lokal mampu dipadukan dengan falsafah bangsa seperti "Bhineka Tunggal Ika", yang tetap merupakan perekat dalam membangun kerukunan dan toleransi antar umat beragama di NTT. Hal ini menjadi modal yang sangat luar bisa dalam menyatukan semua keragaman agar tercipta dinamika kehidupan yang lebih kondusif dari sebelumnya.

Perekat persatuan yang dikembangkan masyarakat NTT dalam memelihara 
kerukunan merupakan potensi luar biasa yang bisa dicontoh oleh daerah lain. Potensi kearifan lokal (local wisdom) di NTT memang berkembang pesat seiring dengan semakin majunya modernisasi yang membawa implikasi bagi nilai-nilai budaya yang sudah mengakar kuat di kalangan masyarakat. Secara sepintas, kearifan lokal (local wisdom) memang terkesan bercorak khas dan hanya dimiliki oleh, berlaku bagi dan diterima oleh kelompok tertentu, semisal masyarakat NTT. Meski demikian, tidak menutup kemungkinan mengadopsi kearifan lokal di daerah lain sebagai rujukan dalam membangun harmoni kehidupan.

Dalam catatan sejarah, masyarakat "NTT" memang dikenal sebagai daerah yang konsisten menjaga kearifan lokal dari berbagai arus perubahan. Nilai-nilai budaya atau kearifan lokal telah mendasari pembentukan bangsa, menjadi pedoman kehidupan bermasyarakat, berbangsa dan bernegara, dan secara khusus mendasari kerukunan dan toleransi antar umat beragama di bumi Nusantara ini. Kerukunan dan toleransi merupakan ciri budaya bangsa, baik secara lokal maupun nasional. Maka menolak atau merusakkerukunan dan toleransi dalam aspek manapun dengan alasan apapun tidak bisa diterima secara kultural, karena sama dengan menolak atau merusak budaya lokal. Di bawah ini terdapat bingkai khazanah berbasis local wisdom yang terus dipelihara oleh masyarakat NTT dalam rangka merajut kerukunan antar umat beragama sebagai potensi luar biasa yang patut dicontoh oleh daerah lain di Indonesia.

\section{a. Khazanah Sosial: Indahnya Perbedaan dalam Keragaman Budaya, Bahasa, dan Etnis}

Khazanah sosial yang multikultural menjadi salah satu potensi strategis dalam membingkai kearifan lokal sebagai episentrum kekuatan fundamental masyarakat NTT. Episentrum khazanah sosial menjadi mozaik yang mengagumkan sekaligus mencerminkan diversitas kultural yang monomental. Tidak heran bila ideologi melting pot Amerika yang memandang diversitas kultural sebagai produk historis yang aksidental dan temporer, justru menjadi konvergensi yang mengakar kuat dalam kehidupan masyarakat NTT. Diversitas sejenis itu disertai dengan etnitas yang heterogen merupakan khazanah sosial yang telah berlangsung lama dan tidak bisa diresistensi oleh kepentingan komunal sekalipun. Khazanah sosial masyarakat NTT tentu saja tidak hanya dicirikan oleh diversitas, melainkan juga oleh pluralitas 
(kemajemukan)-yang memandang dan mengapresiasi diversitas sebagai nilai fundamental dalam sistem sosial-kultural masyarakat. 14

Lalu apa fungsi pemakaian term diversitas kultural dan pluralitas dalam kehidupan masyarakat NTT? Pemakaian tersebut merupakan prinsip struktural dalam menjelaskan dan memahami tatanan kehidupan sosial masyarakat NTT sehingga menjadi sebuah mozaik yang mengagumkan dan dipandang sebagai kekayaan kultural yang tidak bisa ditukar dengan kekayaan apa pun. Karakter mozaik ini memang sulit didiskusikan karena tidak mengikuti skema tertentu, tetapi tetap mencakup banyak dimensi, varian, dan level yang sinergis satu sama lain. Ada beberapa dimensi penting dari variabilitas dan identitas, yang secara bersama-sama menentukan karakter kehidupan tradisional masyarakat NTT, seperti pluralisme ekologis, regional, etnis, agama, dan budaya, keluarga da suku dalam konteks kampung, kelompok kerja dan stratatifikasi sosial.15

Potensi khazanah sosial secara tidak langsung telah mengikat masyarakat NTT untuk membangun sebuah harmoni di tengah keragaman. Buktinya, perbedaan etnis, perbedaan dari aspek asal-usul keturunan (historical descent), dan warisan budaya (cultural heritage), tampak antar wilayah dan interwilayah tertentu. Banyak di wilayah NTT dipisah-pisahkan ataupun dibedakan dari wilayah lainnya oleh bahasa dan budaya (Flores, Sumba Timur, dan Rote; Dawan, Tetum, Lamaholot, Sikka, Ende, Lio, Nage, Keo, Ngdha, Riung, Mangaggarai).

Diversitas etnis lokal yang terbingkai dalam kehidupan masyarakat NTT tidak lantas menjadi penghambat terciptanya kerukunan antar warga, melainkan semakin memperkuat ikatan sosial yang terbangun dari satu generasi ke generasi selanjutnya. Terlebih lagi, dalam etnis lokal ini terdapat sejumlah etnis besar yang bermigrasi dari Jawa, Bugis, Makasar, Cina, dan Arab. Asimilasi kultural yang terbingkai dalam kehidupan etnis lokal dengan etnis pendatang berjalan sinergis dan jarang sekali terjadi resistensi yang sifatnya menyeluruh. Interaksi antar etnis ini memungkinkan

14Anthony Giddens, Sociology (Cambridge: Polity Press, 1993), h. 123.

15Philips Tule, "Membangun Format Kerukunan U mat Beragama di Indonesia Menurut Pandangan Katolik", dalamPhilipus Tuleand Maria Maltildis Banda, Pengembangan Kerukunan U mat Beragama Di N TT, h. 46. 
masyarakat NTT hidup dalam situasi dan kondisi yang harmonis dan damai sehingga asimilasi kultural dapat melahirkan persahabatan yang mengagumkan.

Di sinilah karakter diversitas etnis lokal menjadi potensi dan energi yang menakjubkan guna membangun interaksi sosial secara simultan. Harus disadari bahwa diversitas etnis lokal dari sudut pandang orang luar (outsider) telah menjadi fenomena tradisional yang cukup stabil di NTT. Diversitas etnis lokal maupun kedatangan etnis luar tidak membuat masyarakat NTT merasa terancam atau takut terjadi konflik yang membawa malapetaka bagi kerukunan hidup masyarakat. Justru, diversitas etnis ini bisa dijadikan pelecut semangat untuk semakin memperkokoh ikatan persaudaraan sebagai sesama bangsa. Distingsi etnis semakin diperkuat oleh faktor tradisional lainnya, seperti kekerabatan (kinship), agama (religion), dan ekonomi komunal (common economic). 16

Dengan memperkenalkan khazanah sosial sebagai potensi lokalitas, masyarakat NTT senantiasa terus-menerus menjaga kerukunan yang sudah tercipta agar tidak terkooptasi oleh kepentingan komunal yang bisa merusak harmonisasi kehidupan secara keseluruhan. Karakter mozaik yang terbingkai dalam variabilitas dan identitas masyarakat NTT setidaknya menjadi kekayaan monomental yang perlu dijaga keautentikannya sehingga terhindar dari kepentingan-kepentingan politik yang bersifat pragmatis.

\section{b. Khazanah Budaya Kekerabatan: Modal M enjaga Keakraban}

Dibandingkan dengan daerah-daerah lain di Indonesia, NTT termasuk daerah yang memiliki kekayaan kultural yang menakjubkan. Hampir di seluruh NTT, keluarga memiliki struktur dan fungsi yang hampir sama, meskipun di beberapa wilayah ada varian yang berbeda-beda. Struktur dan sistem yang melekat dalam kehidupan masyarakat NTT secara tidak langsung telah mengakar kuar dalam setiap masing-masing keluarga sebagai khazanah kultural yang majemuk.

Lalu apa struktur dan sistem yang dominan dalam keluarga di NTT? Struktur tersebut adalah apa yang sering disebut masyarakat NTT dengan "patrilineal", yakni kebiasaan menelusuri asal-usul keturunan seseorang hanya melalui garis laki-laki (male line). Seorang isteri diharapkan berpindah tempat tinggal dan bergabung dengan

16Philipus Tule, Longing for the H ouse of G od, D welling in the H ouse of theA ncenstors: Local Belief, Christianity and Islam Among the Keo of Central Flores (Switzerland: A cademic Press, 2004), h. 123. 
keluarga suaminya setelah menikah. Struktur patrilineal ini mencerminkan bahwa keluarga sangat bersifat patriarkal, di mana kepemimpinan senantiasa berada di tangan seorang bapak, hingga kematiannya diambil alih oleh adik lelaki tertua dan seterusnya.

Sebagai pengecualian, sistem ini tidak berlaku di kalangan masyarakat suku N gadha, Tana Ai, dan Betun, yang lebih menerapkan sistem matrilineal. Sementara diantara orang Nage, Keo, dan beberapa suku lainnya, tampaknya menerapkan kedua sistem itu secara serentak, yang lebih dikenal dengan "sistem bilineal (ambilineal). Hal ini berarti bahwa penelusuran asal-usul seseorang dan pewarisan harta (heritage) dan kekuasaan (power) mengikuti garis bapak (patrilineal), sekaligus garis mama (matrilineal). A palagi dalam sebuah keluarga kebetulan tidak tidak ada anak-anak laki, maka suksesi kepemimpinan keluarga diserahkan kepada anak lelali tertua dari seorang wanita yang menikah keluar. ${ }^{17}$

\section{c. Khazanah Agama Asli dan Budaya Rumah Adat: Membangun Rumah Bersama dalam Keteduhan}

A da beberapa keunikan dan kekuatan mozaik yang menjadi episentrum perekat sekaligus pemersatu masyarakat NTT dalam menyikapi diversitas dan pluralitas bangsa. Lalu, apa yang sebenarnya menjadi faktor pemersatu paling fundamental bagi kehidupan masyarakat NTT? Diantara semua faktor pemersatu dan penopang terciptanya kerukunan masyarakat NTT adalah tidak lebih kuat daripada "agama asli" (Kristen) dan "budaya rumah adat". ${ }^{18}$ Dua faktor inilah yang paling dominan menjadi penentu terbangunnya kesadaran masyarakat tentang penting hidup rukun dan damai tanpa memandang diversitas etnis dan pluralitas. Apalagi, Provinsi NTT tercatat sebagai penganut Kristen terbesar di seluruh Indonesia (kurang lebih 3 juta orang Kristen hidup di NTT), sehingga hampir semua orang NTT bangga menjadi orang Kristen (Katolik).

Begitu pula dengan "budaya rumah adat" yang menjadi faktor pemersatu dan pengikat antar individu atau kelompok ke dalam satu komunitas sosial, spiritual, bahkan lintas agama. Eksitensi rumah adat bagi masyarakat NTT merupakan kekuatan atau daya "kebudayaan" yang begitu esensial dalam mengintegrasikan diversitas 
masyarakat sebagai hasil karya, karsa, dan rasa bersama. Heterogenitas budaya yang tumbuh subur di tengah kecamuk bangsa yang dilanda berbagai konflik, bukan merupakan penghalang terciptanya identitas budaya yang lebih integral. Salah satunya terkait dengan potensi luar biasa yang dimiliki bangsa Indonesia, yakni adanya kemampuan untuk mengintegrasikan budaya lokal, tradisi, dan nilai-nilai yang terkandung di dalamnya.Keanekaragaman budaya yang terdapat di NTT harus dipandang sebagai sebuah kekayaan bukan kemiskinan. Bahwa masyarakat NTT tidak memiliki identitas budaya yang tunggal bukan berarti tidak memiliki jati diri, namun dengan keanekaragaman budaya yang ada membuktikan bahwa masyarakat NTT memiliki kualitas produksi budaya yang luar biasa, jika mengacu pada pengertian bahwa kebudayaan adalah keseluruhan sistem gagasan, tindakan, hasil cipta dan karsa manusia, yang terbingkai dalam tiga wujud, yaitu ideas, activities, and artifacts. 19

Maka khazanah "budaya rumah adat" dalam kehidupan masyarakat NTT menjadi bagian dari kekayaan kultural yang terus dipelihara sebagai perekat persatuan antar warga. Potensi untuk mengintegrasikan keseluruhan budaya rumah adat patut dipandang sebagai langkah primordial dalam membangun akulturasi budaya yang terdapat di Indonesia. Integrasi budaya nasional di tengah tilikungan globalisasi dan benturan peradaban (clash of civilitizion) merupakan salah satu nilai kultural yang perlu direvitalisasi dalam prospek pembangunan ke depan.Budaya yang merupakan sumber ilmu pengetahuan, sejatinya harus mampu memberikan inovasi (pembaharuan) terhadap kemajuan suatu bangsa.

Budaya adat dalam konteks ini boleh dibilang dapat menjadi perekat identitas masyarakat NTT yang paling urgen dan signifikan, mulai dari sikap, integritas, dan masa depan bangsa secara keseluruhan. Eksistensi rumah adat merupakan perwujudan dari sebuah budaya lokal yang dianggap memiliki nilai paling luhur, superioritas sebuah budaya kelompok tertentu. Jika memang demikian, benturan yang terjadi kembali pada konteks keragaman yang ada. Apakah ada budaya yang paling kuat dalam keragaman budaya di Indonesia yang bisa mengendalikan budaya lainnya? Misalnya Budaya Jawa atau Sunda mengendalikan budaya yang tersebar di Bali, Papua, Aceh, Sulawesi, Kalimantan, dan NTT sendiri. Tentu saja, kita pun 
kembali harus mengaca pada cermin pancasila dan konsep pluralisme yang ada dan menjawab tidak.20

Potret kerukunan di NTT sudah terbentuk oleh kearifan lokal masyarakatnya yang memiliki karakter khas sebagai etnis lokal yang majemuk. Kehidupan masyarakat NTT tentu saja tidak terlepas dari karakter dominan "budaya adat" dan "budaya kampung" sebagai local wisdom yang diwarnai oleh tiga emas dari tatanan sosial, yakni rumah (uma, ume, sao), kampung (kuan dan knua, serta kanaf untuk orang A tono Pah Meto, fuku untuk orang Tetun Wehali, udu untuk orang Suwu, kabisu atau kabilu untuk orang Sumba), dan tanah (tana). Bagi orang Indonesia Timur, sebagaimana masyarakat Astronesia, konsepnya mengenai rumah ternyata melampaui struktur fisiknya dan makna simbolnya terbingkas dalam bagian-bagian rumah. Dari rumah itu terkandung pula katagori sosial yang fundamental dan relasi antar rumah yang satu dengan yang lain menyiratkan representasi khas lokal dari konsep yang lebih luas, yang lebih dikena dengan term "kelompok seketurunan" (descent group) atau "kelompok seasal” (origin group).21

Karakter khas budaya rumah dan budaya kampung bagi masyarakat NTT merupakan mozaik tersendiri yang tidak lekang oleh waktu dan zaman. Potensi local wisdom masyarakat NTT dengan segala kekhasannya secara tidak langsung menjadi nilai penting bagi pembentukan komunitas sosial yang berwawasan tradisional tanpa terjebak dengan benturan budaya global (clash of global culture).Meskipun masyarakat NTT tidak begitu berkembang seperti daerah lainnya, namun potensi dan kekayaan kultural mereka tidak bisa diabaikan begitu saja.

Berkaitan dengan hubungan antar rumah yang membentuk sebuah "kampung" atau perkampungan (knua, kuan di Timor atau nua di Flores), antropolog Cunningham, misalnya mendefinisikan "kampung di Atoni" sebagai suatu asosiasi dari beberapa kelompok seketurunan atau beberapa rumah yang memiliki nama leluhur atau eum kanaf. Di suku Ema, misalnya, kampung direpresentasikan sebagai "rumah-rumah

20Mohammad Takdir Ilahi, N asional isme D alam Bingkai Pluralitas Bangsa: Paradigma Pembangunan D an Kemandirian Bangsa, h. 117.

21].J. Fox, M emories of Ride Poles and Cross Beams: The Catagorical Foundation of a Rotinese Cultural D esign (Camberra: Depertement of A ntropology, RSPAS, ANU, 1994), h. 170. 
inti" yang berfungsi sebagai praktik aliansi perkawinan serta penyelenggaraan ritusritus kolektif.22

\section{d. Khazanah A gama yang Inkulturatif}

Potret kerukunan yang terjadi di masyarakat NTT juga tidak lepas dari penanaman nilai-nilai keagamaan yang berbasis budaya sehingga potensi konflik pun bisa diredam dengan sangat baik. Mayoritas masyarakat NTT yang beragama Katolik, membuat pembinaan keagamaan mudah dilakukan dalam konteks yang lebih luas, terutama suku-suku yang ada di pedalaman. Pemimpin agama di NTT berusaha mengintegrasikan pesan-pesan injil ke dalam konteks kebudayaan lokal, yang lebih dikenal dengan term teologi inkulturatif.

Teologi inkulturatif tidak sama dengan term-term antropologis yang lebih tua seperti enkulturasi (enculturation) dan akulturasi (acculturation). Sebagai sebauh term misiologis, inkulturasi adalah proses di mana iman kristen diintegrasikan sedemikian rupa ke dalam kebudayaan orang yang menjadi sasaran (goal) pewartaan sehingga dapat diekpresikan lewat anasir budaya itu dan menstransformasikannya dari dalam. Dalam proses itu, kebudayaan pun sebaliknya memperkaya dan menstransformasikan bentuk-bentuk iman kristen yang di bawa ke luar. Kesadaran baru ini telah menjadi fondasi penting bagi pengembangan teologi inkulturasi-yang memiliki lima model, yaitu terjemahan (translational), antropologis (antropological), praksis (praxis), sintesis (synthetic), dan transdental (transcendental).23

Tule, misalnya, membahas tentang inkulturasi di Keo, sebagaimana terekam dalam beberapa perayaan misa inkulturasi di kampung Worowatu. Ia mengamati dan membedah perayaan (ritus) keagamaan tersebut dapat dikatakan bahwa semuanya sesuai dengan model praksis karena telah menerjemahkan pesan-pesan keagamaan ke dalam budaya lokal secara antropologis. Dalam tataran inkulturasi, iman Katolik diintegrasikan ke dalam budaya lokal sehingga iman monoteistik itu dan budaya lokal ditransformasikan dan diperkaya satu sama lain. Sementara dalam tataran akulturasi

22Cunningham, Catagories of D escent in a Timor Village (New York: : Orbis Book, 1966), h. 13.

23Peter C. Phan, M ission and Catechesis: A lexander de R hodes and Inculturation in Seventeenth Century Village (New York: Orbis Book, 1998), h. 194. 
agama monoteistik itu telah saling meminjam dan memanfaatkan elemen masingmasing demi memperkaya khazanah kehidupan religiousitas para penganutnya. 24

\section{Kontribusi Tokoh Agama dan Generasi Muda dalam Memelihara Kerukunan}

\section{Antar Umat Beragama}

\section{a. Kontribusi Tokoh Agama}

Dalam konteks masyarakat NTT, tokoh agama menjadi katalisator dalam mengayomi dan merangkul semua orang untuk bersatu dalam mewujudkan kehidupan yang penuh dengan persaudaraan dan perdamaian sekaligus sebagai antisipasi semakin melebarnya timbulnya gejala-gejala kekerasan yang menjadi tantangan kita bersama. Peran tokoh agama di NTT dinilai masih cukup strategis dan signifikan dalam mengarahkan sikap keberagamaan umat yang cenderung eksklusif. Tokoh agama di sana memerankan fungsi agama sebagai kemaslahatan umat dengan cara mengembangkan interpretasi yang memiliki semangat perdamaian dan spirit kerukunan umat beragama. Tokoh agama sebagai orang-orang yang menjalankan fungsi-fungsi kepemimpinan agama, diharapkan mampu memimpin dan mengarahkan para pemeluk agama untuk menahan segala gejolak demi mencapai citacita kedamaian dalam kehidupan bermasyarakat dan berbangsa sehingga dapat menjadikan agama sebagai landasan etnis. ${ }^{25}$

Secara individual dan kolektif, tokoh agama di NTT dikenal sebagai penyayom sekaligus pembina kehidupan masyarakat. Maka otoritas para tokoh agama ini bermuara dari tiga sumber. Pertama, otoritas dari masyarakat yang berasal dari pengakuan terhadap kapabilitasnya dalam melaksanakan tugas-tugas keagamaan. Kedua, otoritas dari struktur ekleksiastik melalui proses pentahbisan tertentu. Dalam kerangka ini, tidak setiap orang, meski memiliki pengetahuan yang memadai, dapat menjadi secara sah sebagai tokoh agama. Ketiga, otoritas negara berdasarkan pengangkatan atau penunjukan kepada posisi-posisi birokrasi keagamaan yang diciptakan negara. Tokoh agama yang memperoleh otoritas dari negara ini boleh jadi tidak memiliki pengaruh besar, tetapi kedudukan mereka seringkali tidak bisa ditolak,

24Philipus Tule, A gama-A gama Kerabat D alam Semesta (Ende: Nusa Indah, 1994), h. 235.

25N gainum Naim, Teologi Kerukunan: M encari Titik Temu D alam Keragaman (Yogyakarta: Teras, 2011), h. 12. 
sebab dari pandangan tertentu, dapat dianggap mencampuri urusan agama yang dalam pandangan ini adalah urusan pribadi, bukan urusan negara.26

Tokoh agama memang memiliki posisi sentral dalam setiap penyelesaian konflik dan mendorong terciptanya kerukunan antar umat beragama, namun mereka tidak bisa bekerja sendiri dalam meningkatkan harmonisasi antar pemeluk agama. Kita harus memberikan dukungan dan kepercayaan kepada tokoh-tokoh agama untuk melaksanakan dialog yang sehat dan jujur tanpa ada ada kecurigaan dan prasangka yang menghambat tercapainya kerjasama dalam membangun persahabatan lintas iman melalui dialog kultural maupun institusional.

Di tengah semakin maraknya konflik di Indonesia, maka tokoh agama diharapkan tampil sebagai pioner dalam mengembangkan sikap keberagamaan yang menarik simpati dan menghindari sikap permusuhan dengan cara mendeskriditkan ajaran agama yang dianut oleh orang lain. Tampilan tokoh agama yang berupaya menghindari eksklusivitas dan membangun pemikiran keagamaan inklusif, pada akhirnya cita-cita dan gagasan kerukunan hidup umat beragama dapat menjadi kenyataan.

Oleh karena itu, perlunya melakukan usaha-usaha yang sifatnya bottom-up (bukan hanya top-down) dalam mengembangkan kerukunan antar ummat beragama demi terwujudnya integrasi nasional sebagaimana yang telah diletakkan landasannya oleh founding fathers. Di mana kerangka landasannya berupa pembentukan kesadaran para pemeluk agama dan signifikansi pluralisme positif dalam kehidupan agama di Indonesia yang bersifat plural ini.27 Seringkali kita disuguhi oleh klaim-klaim sepihak dari agama tertentu yang pada akhirnya rentan menimbulkan konflik dan ketegangan yang semakin merajalela. Maka, negara yang demokratis seperti Indonesia tidak boleh membiarkan konflik itu terjadi secara beruntun.

\section{b. Kontribusi G enerasi Muda}

Tidak bisa dipungkiri bahwa kiprah dan peran kaum muda sangat besar dalam memelihara dan mengembangkan kerukunan di NTT. Setiap orang mesti percaya bahwa generasi muda akan mampu menciptakan perubahan di masa depan, termasuk

57.

26Azyumardi Azra, Konteks Berteologi D i Indonesia: Pengalaman Islam (Jakarta: Paramadina, 1999), 56-

27Haidar N asher, A gama D an Krisis Kemanusiaan M odern (Yogyakarta: Pustaka Pelajar, 1997), h. 100. 
kualitas model dan metode dialog antar agama. Generasi mudah di NTT semakin terbuka dalam menyikapi kemajemukan dan terus-menerus mengembangkan polapola hidup beragama yang transformatif dan inklusif. Hal ini menjadi potens luar biasa bagi kiprah generasi dalam rangka ikut serta memberikan solusi terbaik terhadap masalah kerukunan yang menjadi dambaan dan cita-cita bersama setiap masyarakat.

Keterlibatan generasi muda NTT dalam dialog dan kerukunan umat beragama dapat dilihat dari aktifitas kampus di Sekolah Tinggi Filsafat Ledalero (Flores), Sekolah Tinggi Kateketik (Flores), dan Fakultas Teologi universitas Artha Wacana di Kupang, dimana -para mahasiswa diajari pengetahuan dasar Islam. Hal yang sama juga mahasiwa Kriten di Universitas Muhammadiyah Kupang yang diberikan Introduksi untuk memahami kemuhammadihan. Pesantren Tarbiyah Modern Walisongo di Ende, malah melibatkan para calon imam VD yang menjalani orientasi pastoral sejak 1997 sebagai guru dan bertugas sebagai bapak asrama santri.

$\mathrm{Hal}$ ini menjadi contoh bahwa dialog antar agama merupakan suatu realita yang dihayati di kalangan generasi muda Flores, di mana mereka menjalin komunikasi satu dengan yang lain dan kedua belah pihak saling memberi dalam kehidupan dan pendidikan. Riset menunjukkan bahwa di NTT kekerabatan konsanguinal (hubungan darah), affinal (perkawinan) dan aneka nilai budaya lokal seperti persaudaraan karena memiliki tanah yang sama (land-sibilingship) dan persekutuan dalam sebuah rumah adat secara signifikan menunjang pola hidup bermasyarakat yang harmonis dan toleran.

Terciptanya kerukunan antar umat beragama melalui dialog lintas iman tidak hanya dibebankan kepada para tokoh agama maupun pemerintah, melainkan juga menjadi tanggung jawab generasi muda yang harus mampu mengembangkan sikap toleransi dalam kehidupan sehari-hari bersama saudara-saudaranya yang berbeda agama. Di NTT, peran dan kontribusi generasi muda mengenai pengembangan sikap toleransi bisa digalakkan melalui kegiatan-kegiatan yang mendorong terciptanya semangat persaudaraan antar sesama. Peran dan kontribusi generasi muda menjadi sangat penting dalam kerangka mendorong terciptanya semangat kebersamaan di tengah perbedaan yang berpotensi melahirkan konflik dan gerakan radikal. 
Dalam konteks NTT, generasi muda mereka berperan penting untuk memulihkan citra Indonesia dari kecaman Internasional yang dianggap tidak mampu menyelesaikan tindakan kekerasan. Merajalelanya aksi kekerasan atas nama agama secara tidak langsung membuat citra Indonesia sebagai penduduk muslim terbesar di dunia tercoreng di bidang kerukunan umat beragama. Citra Indonesia sebagai bangsa toleran dengan kemajemukannya, bisa saja berubah seketika menjadi bangsa yang intoleran dan eksklusif terhadap eksistensi agama-agama. Di NTT, setiap generasi muda sudah memiliki kesadaran dan memiliki tangggung jawab untuk memulihkan citra, membangun kerukunan, dan semangat perdamaian sebagai pilar utama dalam menegakkan nilai-nilai persatuan dan kesatuan yang termanifestasi dalam kebhinnekaan. Perjuangan untuk memantapkan gagasan kerukunan umat beragama tidak bisa dilakukan hanya ketika terjadi konflik, melainkan harus terus menerus sampai mencapai titik temu antar agama-agama. Sebab, tidak ada satu pun agama yang immune, kebal atau lepas dari masalah radikalisme, ekstrimisme, dan fanatisme terhadap penganutnya. Yang paling menentukan dan menjadi kunci kerukunan umat beragama dan wajah perdamaian adalah terciptanya hubungan harmonis antara Islam dan Kristen.

Aktifitas dan kegiatan yang dilakukan generasi muda NTT biasanya dengan mengkampanyekan kerukunan umat beragama sebagai modal sosial dalam membangun dialog yang berkesinambungan. Pembelajaran sikap toleransi yang Ditunjukkan generasi muda NTT menjadi sangat penting untuk mendorong masyarakat lainnya turut serta dalam mempromosikan anti-kekerasan dan menekan sikap diskriminatif terhadap kelompok minoritas yang selalu tertindas. Generasi muda NTT sadar bahwa komposisi pluralitas agama di Indonesia memungkinkan terjadinya resistensi tinggi terhadap munculnya perbedaan dan pertikaian antar pemeluk agama. Tidak heran bila kerukunan dan toleransi beragama merupakan sarana penting untuk memelihara persatuan dan kesatuan nasional yang dapat dimanifestasikan melalui konsep "tri pusat kerukunan"-sebagaimana yang dicanangkan pemerintah. ${ }^{28}$

28Tri pusat kerukunan tersebut sebagai berikut. Pertama, kerukunan antar umat beragama, yaitu kerukunan dan saling menghormati di antara pemeluk berbagai agama. Kedua, kerukunan intern umat bergama, yaitu kerukunan di antara golongan-golongan dalam satu agama. Ketiga, kerukunan di antara 
Dalam rangka memelihara ketiga bentuk kerukunan umat beragama, pemerintah memberikan fasilitas terbentuknya majelis-majelis pemimpin lima agama, yaitu Majelis Ulama Indonesia (MUI), Konferensi Wali Gereja Indonesia (KWI), Persatuan Gereja Indonesia (PGI), Perwakilan Umat Budha dan Parisada Hindu Dharma. Majelis ini merupakan forum komunikasi yang konsen membahas berbagai isu penting terkait dengan harmonisasi kerukunan umat beragama. Selain menjalankan fungsi kordinasi, majelis ini juga berfungsi sebagai penghubung antara penganut agama dengan pemerintah. 29

Adapun format harmonisasi kehidupan antar umat beragama dapat dilandasi oleh kesediaan mengakui dan menghargai otentitas masing-masing ajaran agama30 dan diarahkan pada upaya menghilangkan kesalahpahaman yang selama ini menorehkan goresan tinta yang merusak harmonisasi antar umat beragama. Setidaknya ada empat macam yang harus dipegang setiap penganut agama dalam rangka menciptakan kerukunan dan perdamaian sejati, yaitu komitmen terhadap budaya non-violence dan penghargaan terhadap kehidupan, komitmen terhadap budaya solidaritas dan keadilan ekonomi, komitmen terhadap budaya toleran dan saling mempercayai, dan komitmen terhadap budaya persamaan hak dan kemitraan antara laki-laki dan perempuan. 31

semua kel ompok keagamaan denga pemerintah. Tim Penyusun, Sejarah D epertemen A gama RI: Refleksi 50 Tahun Kiprah D epertemen A gama (Jakarta: Penelitian dan Pengembangan Depertemen A gama RI, 1994), h. 80.

29Sementara fungsi tokoh agama harus memainkan kontribusi signifikan dalam mencipta harmonisasi antar elemen agama yang sedang berkonflik. Hal ini bisa mewujud dalam lima pola sebagai bentuk pencegahan dini (early prevention), yaitu pembiaran dan aliansi (agreement and alliance), perlindungan dan perlakuan sebagaimana mestinya (protection and property), penghargaan dan persahabatan (respect and partnership), sinkretisme dan supersesi (syncretism and supersession), plural isme dan perdamaian (pluralism and peace). Harmonisasi kerukunan antar umat beragama dapat terwujud apabila model konfrontasi dan konflik ditinggalkan sehingga tidak menimbulkan tragedi kemanusiaan yang berkepanjangan bagi penganut semua agama. A bdul A'la, M elampaui D ialog A gama (Jakarta: Penerbit Buku Kompas, 2002), h. 34.

30 Kesediaan untuk mengakui otentitas ajaran agama masing-masing dan menghargai pengakuan orang lain terhadap otentitas ajaran agamanya oleh Alwi Shihab disebut dengan istilah "toleransi yang malas" (lazy tolerance). Dalam toleransi semacam ini, setiap agama mengajak agama lain untuk mengakui keabsahan satu sama lain karena masing-masing mengambil jalan yang dapat memuaskan diri mereka sendiri. Lihat Alwi Shihab, Islam Inklusif: M enuju Sikap Terbuka dalam Beragama, (Bandung: Mizan, 1999), h. 93.

31Tarmizi Taher, M enjadi M uslim M oderat: Beragama D i Tengah Peradaban Gl obal Jakarta: Hikmah, 2004), h. 27. 


\section{PENUTUP}

Para tokoh agama dan masyarakat secara luas yang berkehendak baik tidak boleh terperangkap atau terjebak dengan sistem-sistem atau metode dialog yang kaku dan rigid. Pengalaman menunjukkan bahwa pengembangan dialog untuk tercapainya kerukunan antar umat beragama yang terlalu sistematis seringkali mengalami kegagalan dan kebuntuan di tengah jalan. Hal ini perlu dipikirkan secara matang oleh pemangku kebijakan untuk memberikan ruang yang lebih luas kepada masyarakat adat untuk menyelesaikan setiap konflik yang muncul di tengah-tengah masyarakat.

Sistem dan metode dialog itu bukanlah sebagai sasaran atau tujuan, melainkan sebagai wahana yang bisa membantu para penganut agama untuk membangun komunikasi yang lebih intens, untuk hidup dan mati dalam suatu masyarakat manusia yang lebih humanis, memiliki harapan, iman, kasih sayang, dan cinta damai. Maka, upaya membangun format kerukunan antar umat beragama dewasa ini hendaknya bersifat kontekstual dan inkulturatif, transformatif dan inklusif, serta membimbing orang untuk berpikir positif dan beranjak dari sistem atau metode yang rigid menuju pembelajaran secara kontekstual mengenai spiritualitas sendiri dan sesama.

\section{DAFTAR PUSTAKA}

A bdul A'la. M elampaui D ialog A gama. Jakarta: Penerbit Buku Kompas, 2002. Anthony Giddens. Sociology. Cambridge: Polity Press, 1993.

AP. Budiyono. M embina Kerukunan Hidup A ntar U mat Beriman. Yogyakarta: Kanisius, 1983.

A yatrohaedi. Keperibadian Budaya Bangsa. Yogyakarta: Pustaka Pelajar, 1986.

Azyumardi Azra. Konteks Berteologi D i Indonesia: Pengalaman Islam. Jakarta: Paramadina, 1999.

Chatib Thoha. M embiarkan Berbeda: Kerukunan H idup Beragama D alam Perspektif Keindonesiaan. Yogyakarta: Pustaka Pelajar, 2004.

Cunningham. Catagories of D escent in a Timor V illage. New York: : Orbis Book, 1966.

Eka Darmaputera. Toleransi: Kerukunan Pembangunan. Jakarta: Badan Penerbit Kristen, 1971. 
Eka Hendry Ar. Sosiologi Konflik: Telaah Teoritis Seputar Konflik D an Perdamaian. Pontianak: STAIN Pontianak Press, 2009.

Encon Darsono Wikatma. A gama D an Kerukunan Penganutnya. Bandung: A Ima Arif, 1980.

Fred Wibowo. Kebudayaan M enggugat: M enuntut Perubahan A tas Sikap, Perilaku, Serta Sistem Y ang Tidak Berkebu dayaan. Yogyakarta: Pinus Book Publisher, 2007.

Haidar Nasher. A gama D an Krisis Kemanusiaan M odern. Yogyakarta: Pustaka Pelajar, 1997.

J.J. Fox. M emories of Ride Poles and Cross Beams: The Catagorical Foundation of a R otinese Cultural D esign. Camberra: Depertement of A ntropology, RSPAS, ANU, 1994.

Koentjaraningrat. Pengantar IImu A ntropologi . Jakarta: Rineka Cipta, 1990.

Maulana Wahiduddin Khan. The Ideology of P eace. N ew Delhi: Goodword Books, 2010.

M ohammad Takdir Ilahi. N asionalisme D alam Bingkai P luralitas Bangsa: Paradigma Pembangunan D an Kemandirian Bangsa. Yogyakarta: Ar-Ruzz M edia, 2012.

N gainum Naim. Teologi Kerukunan: M encari Titik Temu D alam Keragaman. Yogyakarta: Teras, 2011.

Peter C. Phan. M ission and Catechesis: A lexander de R hodes and Inculturation in Seventeenth Century V illage. New York: Orbis Book, 1998.

Philipus Tule. A gama-A gama Kerabat D alam Semesta. Ende: Nusa Indah, 1994.

- - - Longing for the H ouse of G od, D welling in the H ouse of theA ncenstors: Local Belief, Christianity and Islam A mong the Keo of Central Flores. Switzerland: A cademic Press, 2004.

Philipus Tule, and Maria Maltildis Banda. Pengembangan Kerukunan U mat Beragama D i NTT. Maumere: Ledarero, 2007.

Tarmizi Taher. M enjadi M uslim M oderat: Beragama D i Tengah Peradaban Global . Jakarta: Hikmah, 2004.

Tim Penyusun. Sejarah D epertemen A gama RI: Refleksi 50 Tahun Kiprah D epertemen A gama. Jakarta: Penelitian dan Pengembangan Depertemen Agama RI, 1994.

Zakaria Beni Makin. M asalah A dat Di Suatu Paroki N TT. Yogyakarta: Pusat Pastoral, 1982. 